\title{
MONUMENTS, CIVIL WAR AND LOCAL COMMUNITIES Archaeological Heritage in the Duhok Region (Kurdistan Region of Iraq). Part 3
}

\section{ESZTER SPÄT ${ }^{1}$}

Hungarian Archaeology Vol. 9 (2020), Issue 3, pp. 43-50. doi: https://doi.org/10.36338/ha.2020.3.5

This third and final part in a series of articles on the archaeological heritage of the Duhok Region of Iraqi Kurdistan will look at the heritage and its role in the life of local society from the aspect of destruction left by the Saddam regime. The decades of Saddam's rule left an indelible mark on the social and cultural map of Northern Iraq, especially on the Kurdistan Region. His attempts at collectivization, sometimes in the name of modernization, sometimes as a punitive military measure against the local population, redrew the settlement pattern of the region, changed the traditional economic and social structure and destroyed much of the built heritage. ${ }^{2}$ Some of this were historical monuments like the medieval monastery of Seje described below. Others, like village mosques, churches, local shrines, graves of saints, even houses where generations grew up, were of importance "only" for the local communities. These buildings were not discussed by scholarly studies, and they mainly remained unrecognized by academic research. However, their annihilation represented a rupture in the cultural fabric of the region, a loss keenly felt to this day. This is the case of the old Yezidi village of Khanke and the shrine of Bayazid.

\section{MONASTERY OF MAR YAKOUB (SEJE MONASTERY)}

The ruins of the Monastery of Mar Yakoub (Saint Jacob) and of the village once surrounding it, lie on the slopes of the Duhok mountain, northwest of the town of Duhok and just north of the small town of Semele (a Christian town in the past.) ${ }^{3}$

According to the 1980 guidebook of Katalin Czellár, a historian of architecture (CzELLÁr 1980, 294), the original monastery was founded in the seventh century. The monastery was abandoned at the beginning of the eighteenth century and a small village was built over its ruins. As she writes: "the church of the monastery still stands, albeit not in the best of conditions, and still retains its eleventh-century architectural character." Today only the foundations of various buildings can be seen, as well as the walls of the orchards constructed on the mountain slope by the former inhabitants. The road leading to the monastery starts a few hundred meters above the village of Seje, just behind a concrete-block farm building. The dirt road runs in a valley next to a river bed (dry in winter, but probably carrying water in the spring) and eventually becomes a badly-worn narrow path carved into the rock, clearly the work of the past inhabitants of the monastery. After a kilometer or so the road forks. The right side leads up to the monastery through a serpentine lane which still retains traces of its former stone-paving. The left one leads through a narrow valley hiding the abandoned, terraced orchards of the former inhabitants as well as remains of a now dry irrigation ditch lined with stones. It ends in a very steep mountain side which appears to have once had a path leading to the monastery above, but apart from the few first meters, this has completely eroded, making the climb to the monastery somewhat dangerous.

According to local oral history, the Christian village and the church next to it was bombed by Saddam in retaliation for the locals supporting the Peshmerga, the Kurdish mountain guerillas fighting against Baghdad's repressive regime. The destruction of the village supports locals' claim that (at least some) Christians also supported the Kurdish movement, despite their ethnic identity as "Assyrians" rather than Kurds (SPÄT 2019, 31-32).

The inhabitants of the mountain village were then moved to the plain at the foot of the mountain, to secure easier control over the people. Presently the new village, Seje, has a mixed population consisting of

\footnotetext{
Independent researcher. E-mail: spateszter@yahoo.com

2 On the politics of collectivization under the Ba'ath Regime, see Wachtmeister, SHekHani \& Recchia 2010.

36 55’ 43.02”N, 42 53'56.45”E (FALK-Dulz [n.d.]).
} 


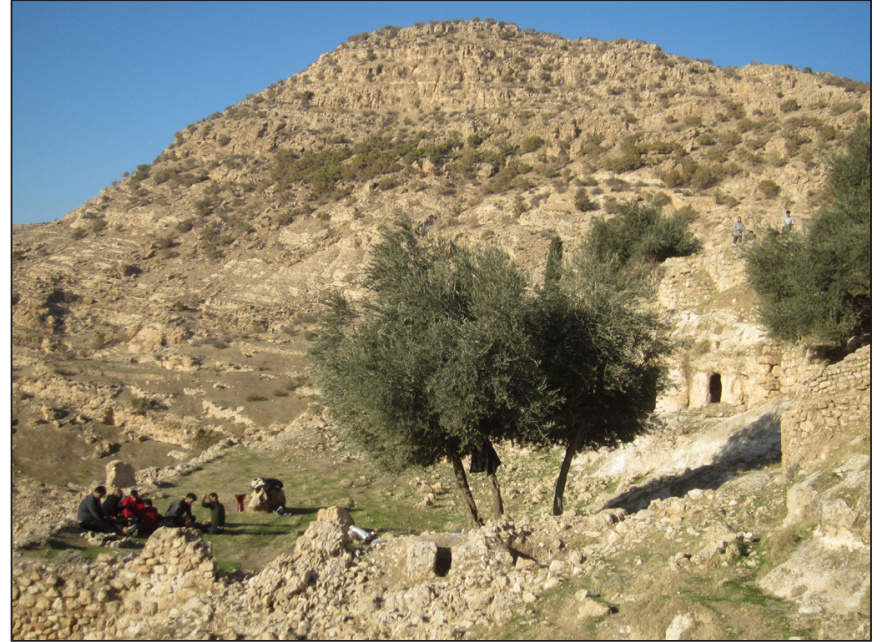

Fig. 1. Picnic among the ruins (Photo by E. Spät)

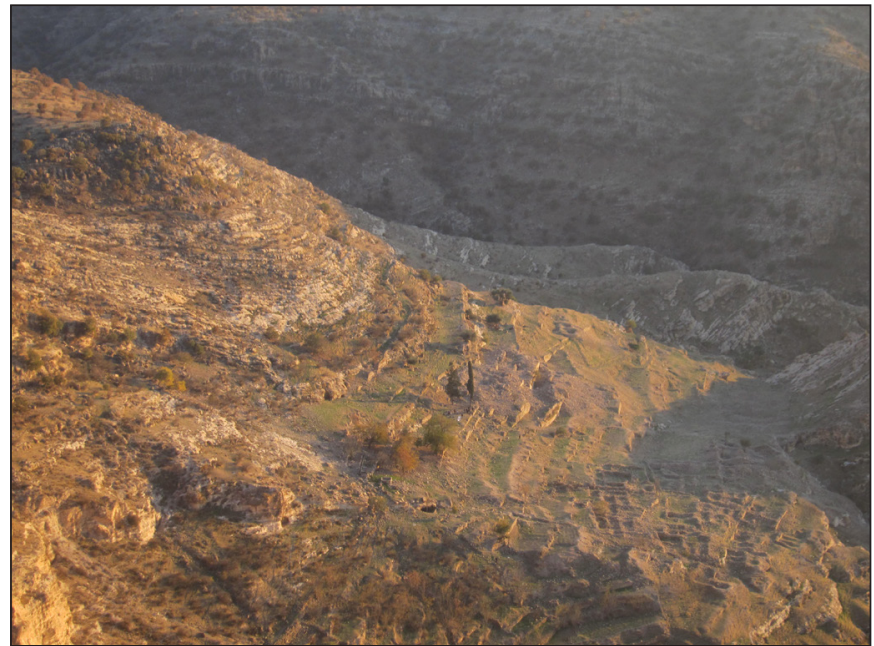

Fig. 2. A view of the ruins of the monastery and the village around it from the hill above (Photo by E. Spät)

local (Chaldean) Christians, Christian refugees from the Niniveh province and Yezidi refugees from Sinjar, who have fled ISIS. According to Noe Falk's Hikes in Kurdistan "every year in May the people go on a pilgrimage to the site to commemorate the village." It is likely that in reality this refers to the shanader, or yearly feast of a church or rather its patron saint. These feast days of patron saints are important ceremonial and social occasions in the life of the Christian population of the Kurdistan Region. They are celebrated with a procession, a mass, a feast in the churchyard/cemetery and even the sacrifice of goats and sheep. Shanaders prompt not only former villagers who have moved away to come back for a visit, but they also attract other Christians (even from as far as Baghdad, if the roads are safe.)

On ordinary weekends, the ruins are a favorite picnicking place for Duhoki Muslim men, willing to do the forty-minutes climb (Fig. 1). There are no social rules against men and women picnicking together - in fact, this is a favorite holiday activity. However, women only go, if the picnic site can be accessed by car, whether that means a scenic spot or just the side of a busy highway. As some middle-aged men preparing a barbecue by the monastery said, their wives "would not be able climb up the mountain," though they admitted that this may change, as the lifestyle of the younger generation is changing. The popularity of the Seje monastery as a picnic destination is painfully attested by the garbage littering the site. Empty shells are also scattered around in the canyon below, as young men like to practice shooting their AK47s among the ruins.

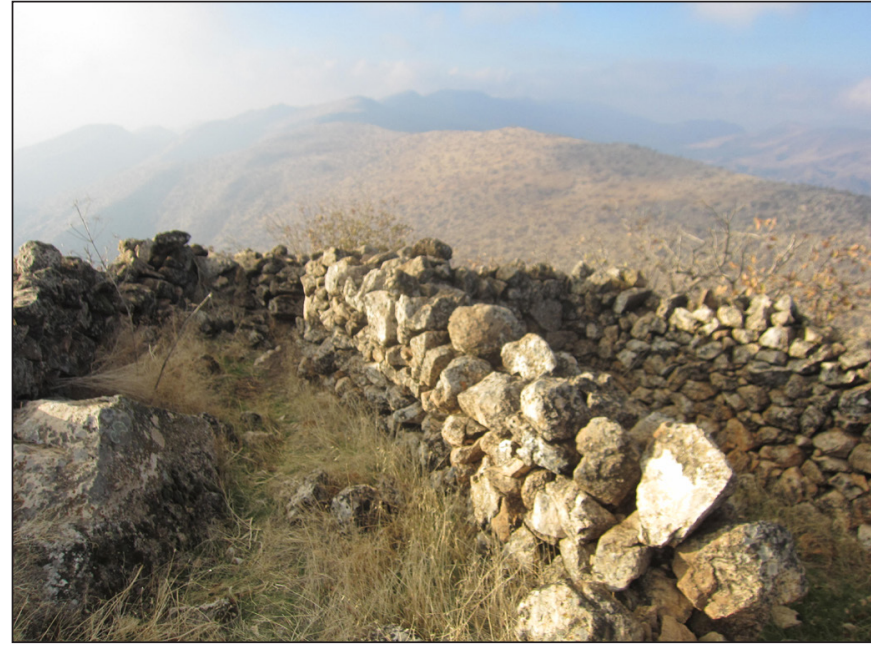

Fig. 3. The ruins of a mysterious fortification on the mountain peak (Photo by E. Spät)

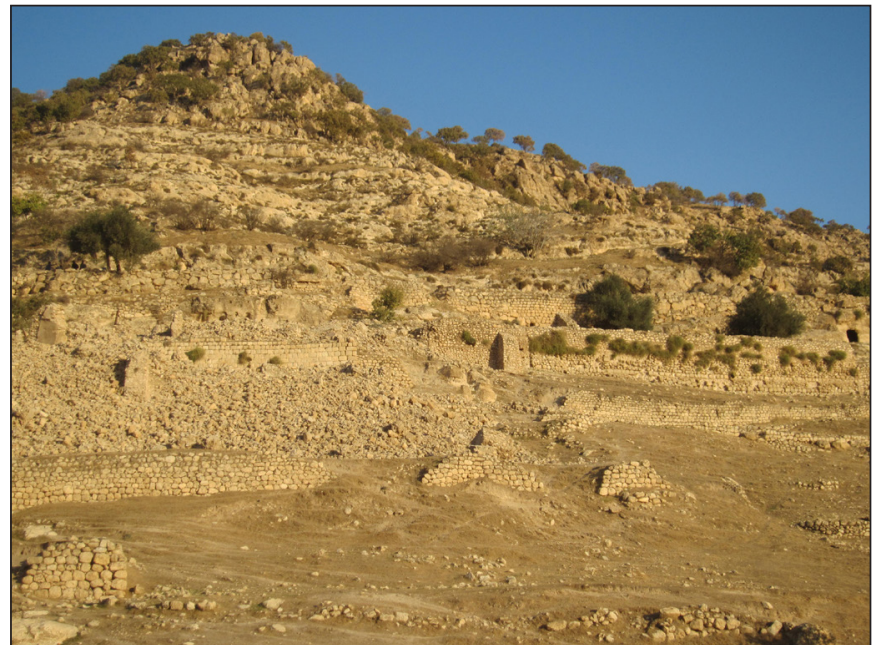

Fig. 4. Ruins of the Mar Yakoub monastery (Photo by E. Spät) 
Just below the plateau, there are a number of caves carved into the cliff. Similar caves can be found inside the village and all over the mountainsides - some of them no longer accessible as the rains have eroded the steps carved into the façade of the rocks.

The ruins are extensive, covering a much wider territory than the average ruined Kurdish village, and the houses also seem to have been bigger (Fig. 2, 4, 5). Many such ruined villages can be found all over Kurdistan, as most Kurdish villages in the mountains were destroyed at one point or another. The mountain slopes around the former monastery/ village are covered by walled terraces once cultivated by the inhabitants. There are also two under-

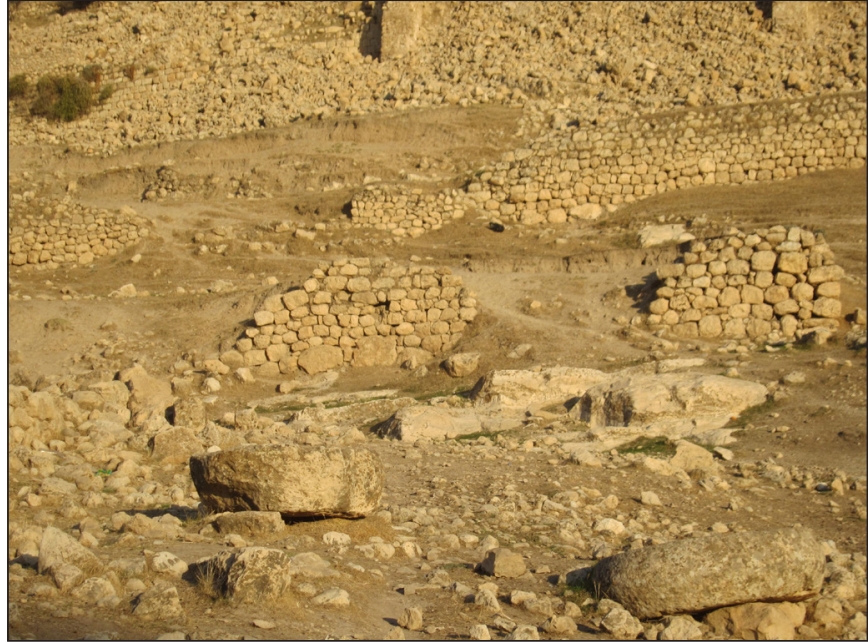

Fig. 5. Ruins of the Mar Yakoub monastery (Photo by E. Spät) ground water canals leading the water of mountain springs to the village. One is dry, but the other one still functions, providing fresh water for the picnickers. ${ }^{4}$ A small hill rises opposite the monastery (toward the Mosul lake), its side is covered with old gravestones and there is a small, ruined chapel on the top.

About half an hour further climb in northwest direction from the village there are the ruins of a small fortification on top of a mountain (Fig 3), offering a good view of the "Doski-valley" below (so-named after the Doski tribe, once powerful in the region). There was absolutely no information available on the origins or use of the fortification. It is questionable if anybody even knows about it, as Kurds are not in the habit of climbing mountains at random, and as this mountain top offers no view of the Niniveh plain, it had no military importance in the past decades.

\section{THE PAST UNDER THE MOSUL LAKE}

The Mosul Lake (formerly Saddam Lake) was created in 1985, when the Mosul (Saddam) Dam, right above the town of Mosul, was constructed. The artificial water reservoir inundated many Arab, Kurdish, Christian and Yezidi villages on both shores of the river Tigris, swallowing the built heritage of their past.

This was the fate of Khanke, a Yezidi village. The village disappeared under the waves and its inhabitants were moved to higher ground, along with another Yezidi village, Rebibi and the Muslim Kurdish village of Kamona. Just a few years later, in 1988, when Saddam forced most of the population of the Kurdish Region into mujamaats, or collective villages much easier to control, a number of other Yezidi villages on the surrounding Duban plain joined Khanke in its new location. The sprawling new Yezidi mujamaat, consisting of 13 villages, was named Khanke after the first village. The original Khanke lost not only its houses and agricultural lands, but also its village shrine, dedicated to the holy being Bayazid, the "protector" of the village. Such village shrines have played (and continue to play) immense importance in the religious and social life of Yezidis. Yezidis follow an oral religion, where instead of a formal knowledge of religious texts or tenets, it is ritual life that creates religious identity and ensures the perpetuation of the religion. Village shrines are in the center of much ritual activity. The dead are buried next to the shrine, new brides are brought there, yearly shrine-feasts are important social occasions attracting visitors from other communities, and women visit the shrine and the graves around it on the occasion of every holy day. Interestingly, the shrine of Bayazid (which served as a village shrine for both Khanke and Rebibi) was not built next to the

\footnotetext{
Such artificial water courses were repeatedly described by Austen Henry Layard, the nineteenth century archaeologist and traveler, throughout the Christian districts of the Kurdish mountains, as were the small gardens which were created on the slopes of every ravine - sometimes through the means of carrying topsoil there from other places. See LAYARD 1867, 131, 136, 153,160 .
} 
village, but a few kilometers from it, on the banks of the river Tigris in an isolated spot. Consequently, the shrine was visited by the villagers only on the occasion of holy days or weddings and burials. People still recall how they had to cross a river ${ }^{5}$ in order to reach the shrine of Bayazid. The river's mouth was not deep, but it was several meters wide. Some people just waded across it, but in bad weather, or when a bride in her wedding finery was being taken to the shrine, people crossed on horseback or just went by boat. Nobody knows why the shrine was so far away. Some think that perhaps at one point in the past there was a Yezidi village next to it. Tribes and villages are known to have repeatedly migrated in the past. According to the oral history of Khanke, even the inhabitants of Khanke itself once lived in another village called Keshkok on the other side of the Tigris. They still refer to themselves as the Keshkoki tribe or clan. Khanke itself, so they say, was first a Jewish village and then a Christian one. No one knows why the Keshkoki moved to Khanke, but today Arabs are said to live in their original village.

Whatever the explanation, the original shrine of Bayazid went under water. Despite the strict religious taboo among Yezidis on creating new sacred space (which can be created only by the presence of holy beings who once walked the earth in human forms), a new shrine was built, as the village just "needed" its shrine and cemetery. The new building was erected on a secluded hill top next to the village, with a lovely view of the new lake. Such scenic spots are usually seen as "pure" by Yezidis. Soil as well as sacred objects were brought from the original shrine, believed to transport the supernatural power of the holy being which permeated the original sacred space. New graves soon sprung up around the shrine, and ritual life continued on the new spot. However, the material remains of their past, sunk under the lake, never stopped to fascinate the villagers. Whenever the waters of the lake fell in the dry season, there was excited speculation, whether the roof of the school (the only building that remained standing as it was made of concrete unlike the private dwellings made of mud-brick and stone) would become visible, and if it did, people went to visit by fishing boats.

The fall of 2017 finally offered a unique chance to revisit places believed to have disappeared forever. Over the passing years the Mosul Dam had become dangerous. International experts had been warning at least since 2003 that the dam could break at any moment, sweeping away settlements along the Tigris, Mosul first and then Baghdad. Worries rose after June 2014, when ISIS took over Mosul. Many were afraid that ISIS, in a suicide move, may decide to blow up the dam, while the military situation made any work on the object impossible. At long last, after the victory over ISIS, the reconstruction of the dam started in 2017 by an Italian company. I have little knowledge of the technical details, but in the fall of 2017 the water level of the lake started falling radically, allegedly as a part of the plan of draining the lake while fixing the dam.

The fast receding water levels caused great excitement among the locals, especially among those whose original villages were under the lake. There was general jubilation in Khanke, when the roof of the school building appeared. The elation grew when the water kept receding and it became possible to climb up on the roof and then eventually the whole building appeared. Inhabitants of the collective village started visiting the shore (normally the bottom of the lake) to have a picnic and to look for relatives and acquaintances among the fishermen, willing to give them a boat ride to the school building (Fig. 6). Eventually, some even started having picnics on the "school ground" (Fig. 7). As a strip of land emerged from the water, connecting the site to the shore, even a TV crew from Kurdish

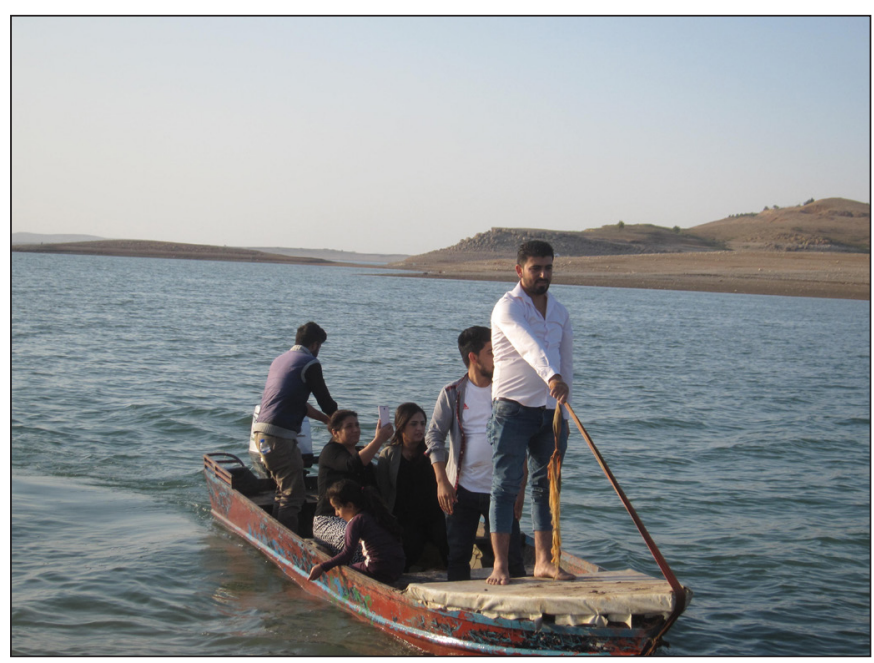

Fig. 6. Villagers take a ride to the school building with the fishing boat of a relative (Photo by E. Spät) 
Eszter Spät • Monuments, Civil War and Local Communities.

channel, VAAR rolled up and made a short news reel, showing what little remained of the village and the villagers reminiscing over the past.

Exciting as the reappearance of the old school and village was, people were even more thrilled at the thought that the shrine of Bayazid, with the graves of their parents, grandparents or spouses around it, may soon appear from the water. They kept steering their boats toward the spot where the shrine of Bayazid lay submerged, in the hope of catching a glimpse. My first boat ride on the lake in mid-November, with a local family of friends, caused great disappointment to the elderly grandmother, who was hoping to see her husband's grave. The shrine and surrounding cemetery were still too deep under the water to be seen. As the water levels continued

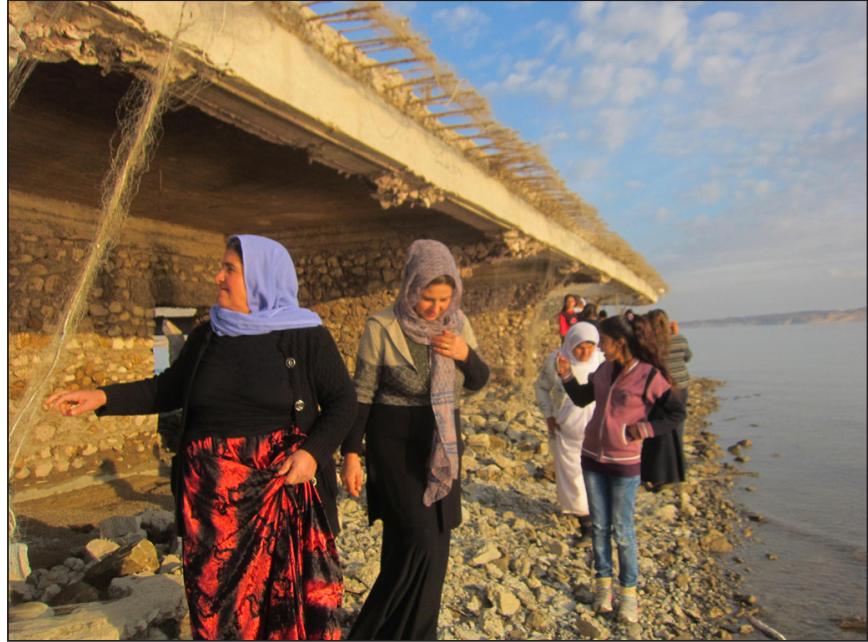

Fig. 7. Village women walking around the remains of the old school building (Photo by E. Spät)

to drop slowly but steadily, it was first teenagers and young men who, by way of adventure, maneuvered their boats among the still half submerged graves, trying to wash off the mud covering the stones. Photos were taken and videos made on the ubiquitous mobiles to be proudly shared with the rest of the community. My attention was specifically called by a young friend to a "Zoroastrian symbol" as he put it, on one of the graves. The rather hazy mobile photo showed an image distantly resembling that of a Zoroastrian faravahar, the figure of a man with open wings. The ancient figure is much used as a nationalist symbol both among Persians and Kurds these days. On further examination, when I managed to visit the graves myself, the

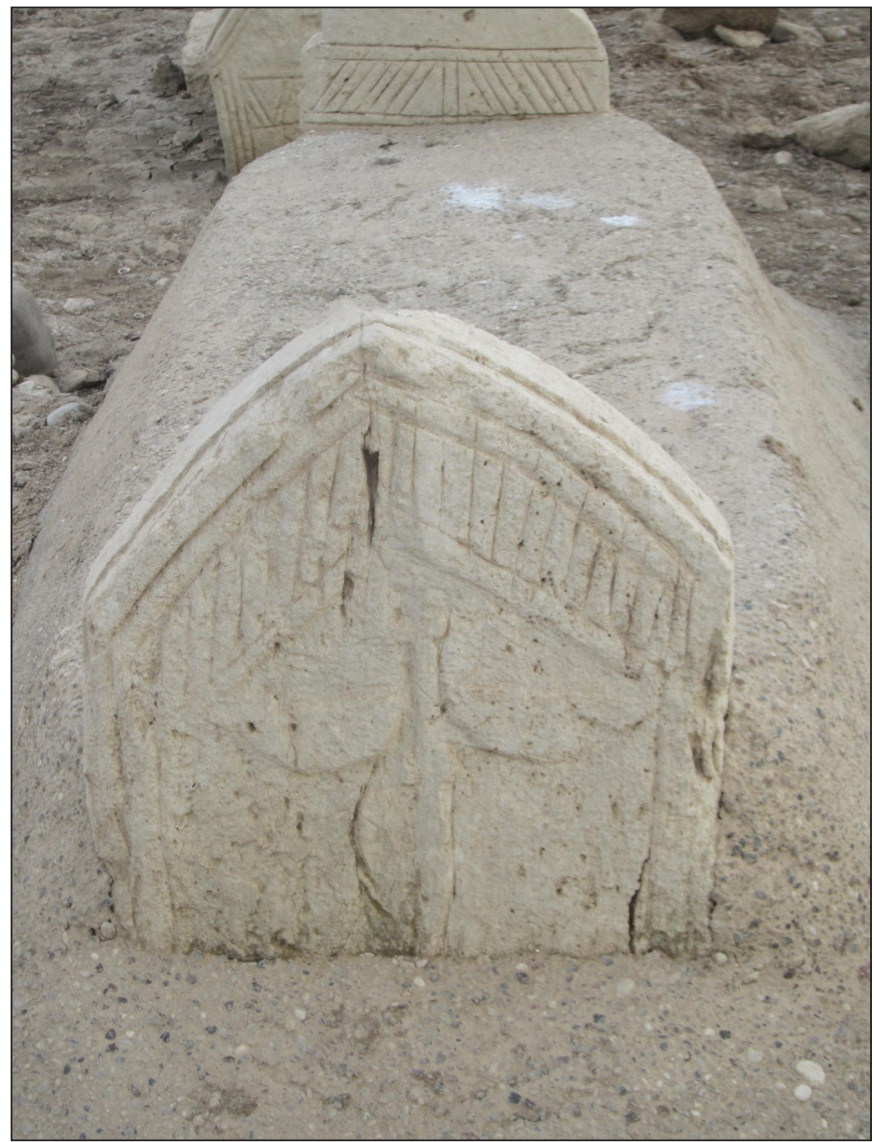

Fig. 8. A grave with a bird symbol interpreted as a representation of the Zoroastrian faravahar symbol (Photo by E. Spät) image proved to be the crude representation of a bird with open wings (Fig. 8). Birds are not unknown to adorn Yezidi tombstone. Even at Bayazid there was another tombstone displaying a bird, even though most graves had only unmarked stones (Fig. 9). With its open wings, the alleged "Zoroastrian symbol" may have been meant as a representation of the Peacock Angel, the protector of Yezidis, or perhaps just an ordinary bird. Its identification with the faravahar spoke volumes not of the religious ideas and

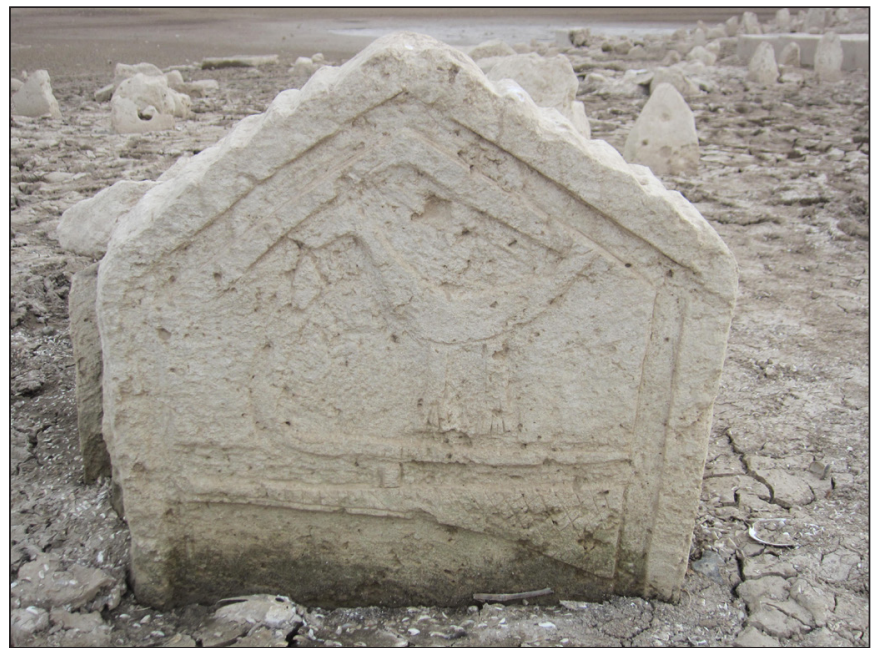

Fig. 9. Grave marker with a bird image (Photo by E. Spät) 
Eszter Spät • Monuments, Civil War and Local Communities.

intents of those who once erected the tomb, but of the impact of decades of nationalist myth-making on the consciousness of today's Yezidis. Not only does modern Kurdish nationalism consider Zoroastrianism the original religion of the Kurds and Zoroaster a Kurd born in Media, aka Kurdistan, but Yezidism has also been represented as the modern-day survival of this ancient Kurdish religion, a view which for decades spread among Yezidis. Though Yezidi elites no longer subscribe to this view, instead pointing toward an ancient Iranian-Yezidi "Mithraism" predating all other religions, the enthusiastic "discovery" of the alleged Zoroastrian tombstone indicated how deeply the idea of ancient Zoroastrianism has become engraved in the consciousness of today's Yezidi and, in general, Kurdish youth.

When at long last, at the end of November, the

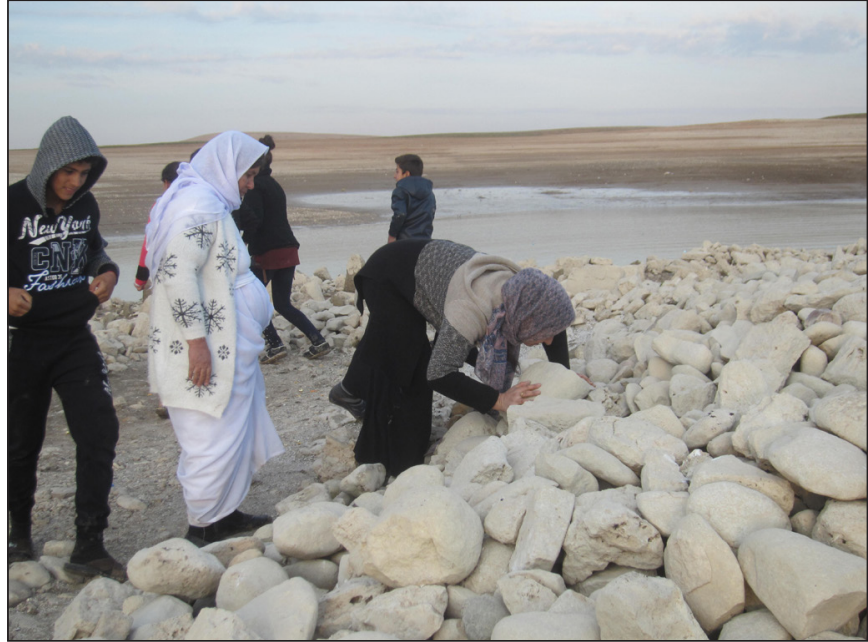

Fig. 10. Women kissing the stones of the ruins of the shrine of Bayazid (Yezidis normally kiss the threshold of their shrines when visiting) (Photo by E. Spät)

shrine (now only a heap of stones) and the cemetery around it fully emerged, it became a real center of pilgrimage for locals, even from villages that had their own shrines. First they arrived with (sometimes dangerously overloaded) boats, then as the water kept receding, by car from the direction of the Duhok-Mosul road, driving over what is under normal circumstances the bottom of the lake. ${ }^{6}$ On the one hand, visiting the shrine and cemetery offered a novelty and a new place to have a picnic. On the other hand, for those who still remembered the old village and had loved ones buried at the cemetery under the lake, it was a genuinely emotional and even spiritual experience (Fig. 10). People did their best to identify the graves of their family members. Not an easy feat, because it is only recently that people have started erecting European-style tombs, possibly under the influence of the Western diaspora, with engraved texts, and decorated with colorful images and even photos. Traditional Yezidi graves were marked only by simple stones. This was very clearly demonstrated by the cemetery, which went underwater in 1985. As can be seen in the photos, most tomb-stones were only that - pieces of stones. An elderly woman claimed to recognize her

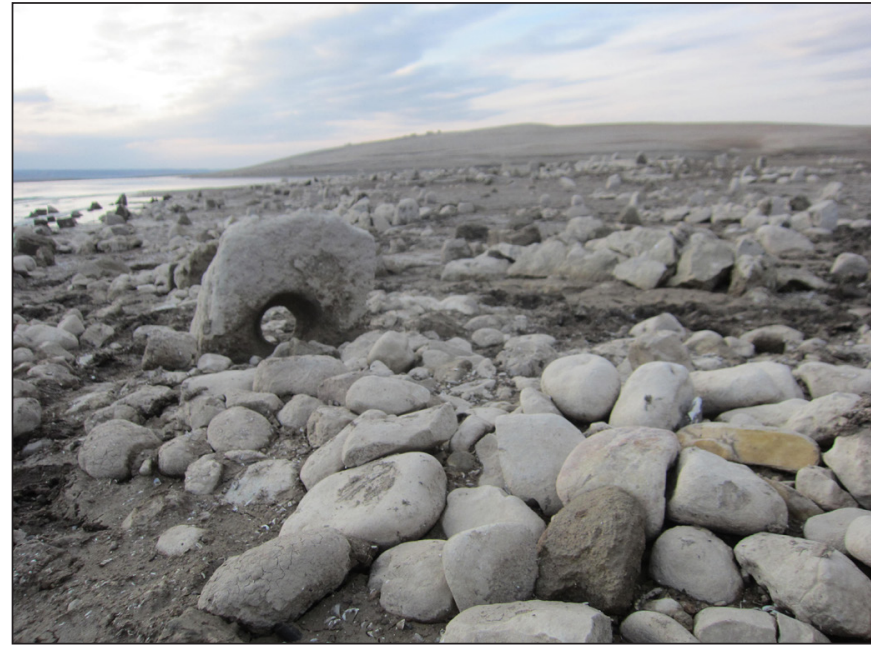

Fig. 11. Stone with a round hole, marking a grave (Photo by E. Spät)

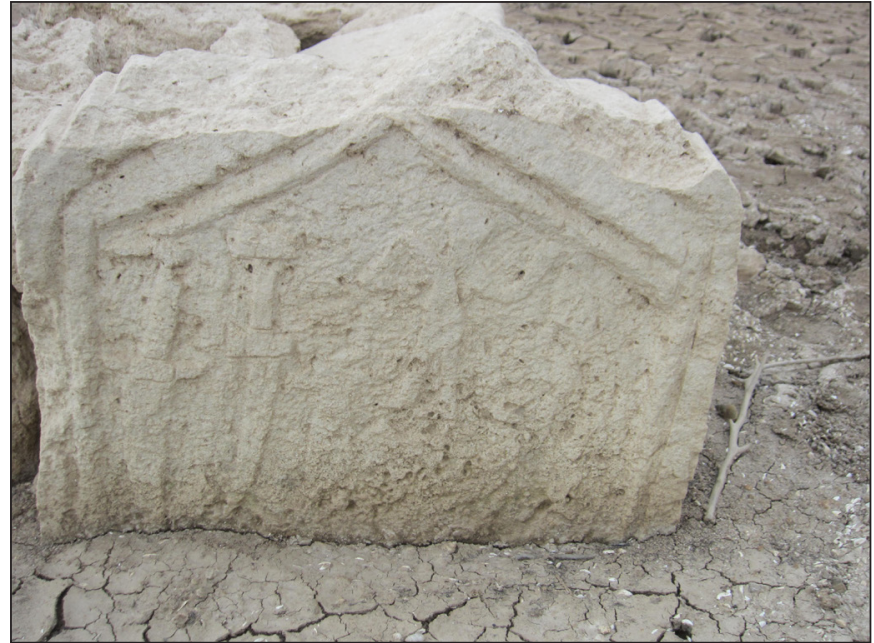

Fig. 12. Grave marker with daggers (Photo by E. Spät)

$6 \quad$ As I eventually figured out, walking to the shrine was also possible, however this took a good four-five hours of walk, there and back. I was the only one to choose this method, since I didn't have a car, but at least it gave me a good idea of what getting to the shrine of Bayazid must have been like back in the time before cars and motorboats. 
Eszter Spät • Monuments, Civil War and Local Communities.

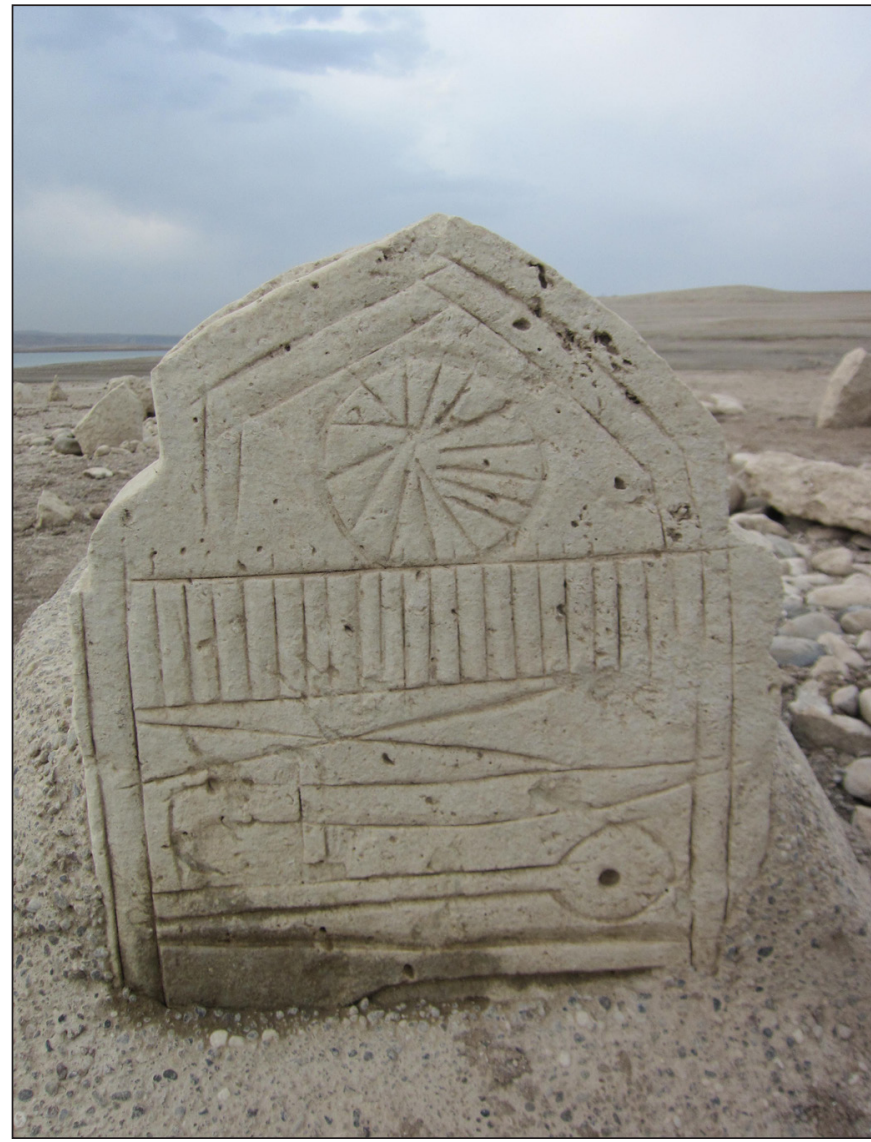

Fig. 13. A grave marker with the traditional Yezidi symbol of sun disc, and scissors and a spoon (Photo by E. Spät)

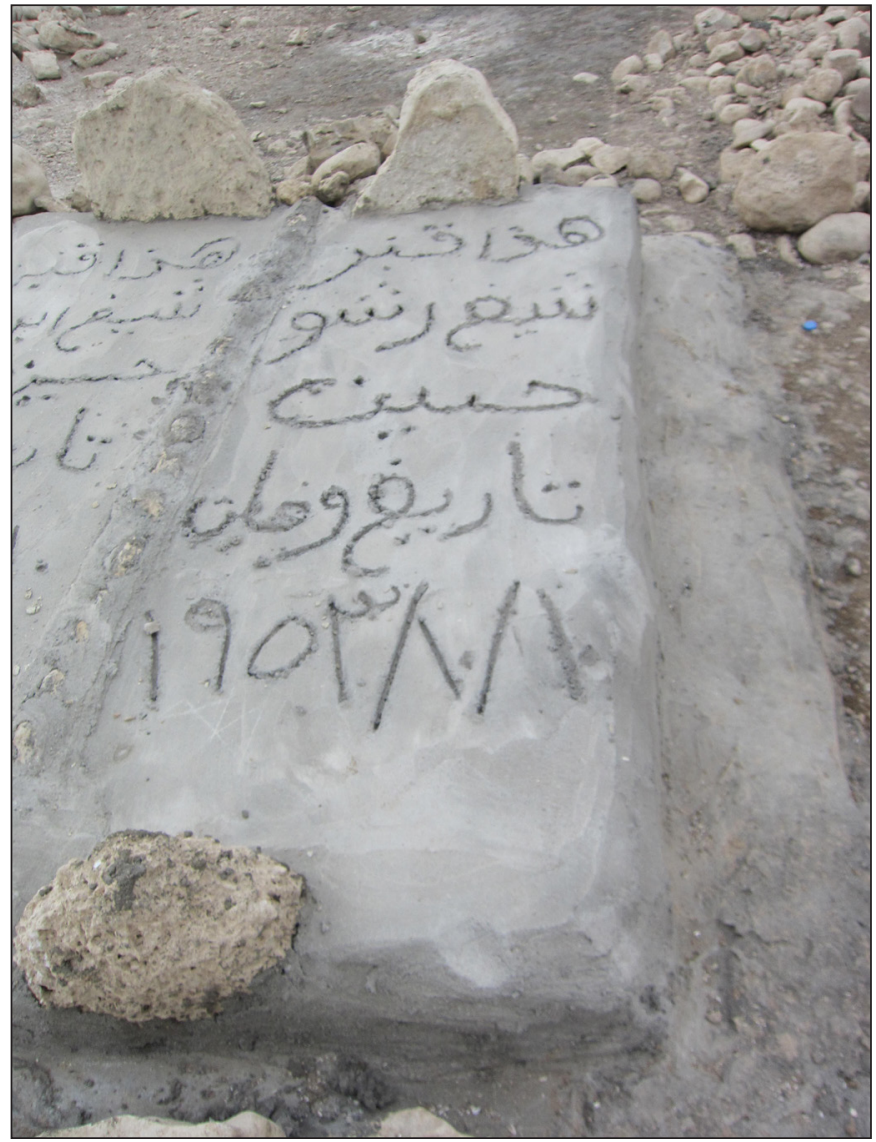

Fig. 14. Newly erected concrete graves replacing the old stone markers (Photo by E. Spät)

mother's grave because she remembered it was marked with a stone with a round hole in it (Fig. 11). As she said, back then, this was the only way to make a grave identifiable. A few graves, like the one with the "Zoroastrian symbol" had headstones with some rudimentary symbols carved into them: a bird, daggers (perhaps the grave of a soldier) (Fig. 12), sun-discs, scissor and stirring spoon (for housewives) (Fig. 13) and mysterious geometric forms, no one any longer knew what they meant. However, judging by the concrete slabs into which the headstones were embedded, even these graves were relatively modern. Some of those who recognized the graves of their relatives rushed to erect new, more-lasting tombs over them before the water returned. They covered the graves with huge concrete slabs complete with the names, dates and some pious epithets (Fig. 14). A few of the old graves were constructed in similar manner, indicating that marking graves with names, etched into the still soft cement, must have started in the 80s' (Fig. 15). The fashion, these days, is to erect tombs made from faux-marble, often with pillars and a "roof", or wrought iron fences around them, but simple concrete slabs would be more likely to last under the water. Just as on the eve of holydays, the villagers brought food to be put on the graves, and some even brought artificial flowers to put on the graves (Fig. 16). This is yet another new fashion introduced by those living in the Western diaspora;

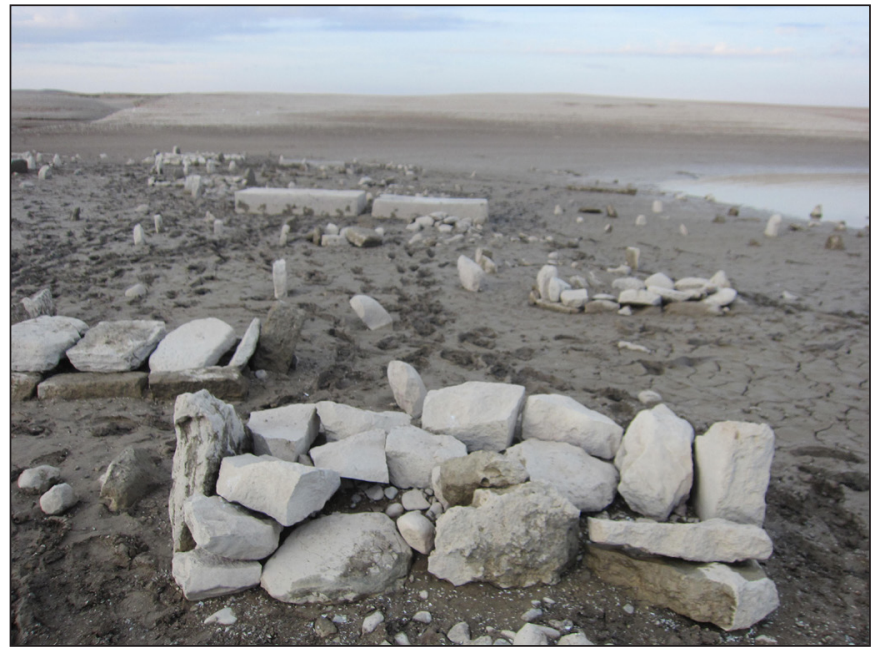

Fig. 15. The cemetery emerging from the lake, amid the traditional stone markers, two concrete slabs are also visible (Photo by E. Spät) 
Eszter Spät $\bullet$ Monuments, Civil War and Local Communities.

the same is true for planting flowers on the graves, a habit I first observed in 2017. Small oil lamps, traditionally lit on the eve of every holyday at sacred places, were lit at the spot that was believed to have once been the entrance of the shrine. The last remaining religious expert of the collective village of nearly twenty thousand inhabitants was invited to recite prayers and hymns over the graves. ${ }^{7}$

Eventually the water returned and covered everything again. However, the villagers now have photos of the shrine and graves on their mobiles as keep-sakes to look at from time to time. (Apparently, no photos were taken at the time of the Beyazid shrine, or of the other shrines which went underwater in 1985, as taking photos was not yet a part of everyday Yezidi culture.) Some people even made the photo of the briefly recovered grave of

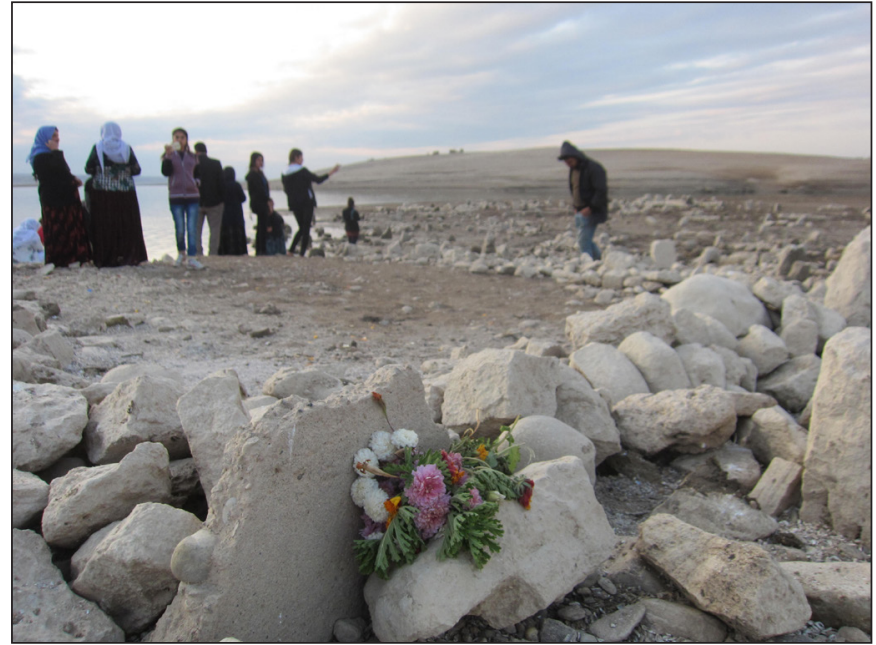

Fig. 16. Artificial flowers decorating a grave, a novel practice introduced by the European diaspora (Photo by E. Spät) their loved ones into their Facebook profile pictures, or shared VAAR TV's report on the village on their Facebook page, helping to preserve for posterity the memory of a past that had once again disappeared under the lake.

\section{BIBLIOGRAPHY}

Czellár, K. (1979). Irak [Iraq]. Budapest: Panoráma.

Falk, N. \& Dulz, I. [n. d.] Hikes in Kurdistan. Unpublished manuscript.

Layard, H. A. (1867). Niniveh and Its Remains: A Narrative of an Expedition to Assyria During the Years 1845, 1847 and 1847. London: John Murray.

Spät, E. (2019). Monuments, civil war and local communities: Archaeological Heritage in the Duhok Region (Kurdistan Region of Iraq). Part 1. Hungarian Archaeology Vol. 8, Issue 1 (2019), 28-34.

Spät, E. (2020). (Forthcoming). Displacement, Loss and Transformation: Yezidi Ritual Life in Iraq. In K. Omarkhali and P. Kreyenbroek eds., Yezidism between Continuity and Transformation. Wiesbaden: Harrassowitz.

Wachtmeister, A., Shekhani, A. \& Recchia, F. (2010). Spatial Design and Social Control: Collective Towns in Iraqi Kurdistan. ArteEast Quarterly http://www.arteeast.org/2012/02/11/spatial-design-and-social-controlcollective-towns-in-iraqi-kurdistan/ (Last accessed 19 December, 2015). 